\title{
Organic Farming: Status, Challenges and towards Sustainable Agriculture
}

\author{
Lanje Shivaji Namdevrao* \\ Lovely Professional University, Department of Agronomy, Lovely Professional University, \\ Phagwara, Punjab, India \\ *Corresponding author
}

\section{A B S T R A C T}

\begin{tabular}{|l|}
\hline Key w or d s \\
Organic Farming, \\
Sustainable \\
Agriculture
\end{tabular}

In this paper, the global and Indian scenarios about organic farming have been reviewed. In India, the cultivated land under certification is just 2.8 Mha. Yield declines in organic farm conversion, enhancement of soil fertility, introduction of animals, certification restrictions, biodiversity, marketing and policy support are the key concerns arising in organic farming. The potential, especially in the drylands, for organic farming has been discussed. The rise in global awareness of health has made organic farming and organic products more popular globally. Fresh food, rather than a commodity alone, is used as a health element. The new face of Indian agriculture is organic farming, but it faces many challenges. In the near future, intelligent policy, scientific planning, responsible public action and government funding will help to address these challenges. Organic farming supplies macronutrients and micronutrients to plants and thus improves the physical, chemical and biological properties of the soil. Organic farming is considered to be better than traditional farming due to increased human labour, lower cultivation costs, better profits, increased input production capacity and minimized risk resulting to higher incomes, enhanced farmers' self-dependence and socioeconomic stability, and conservation of soil health and climate.

\section{Introduction}

Among the developing countries in the world, one of the fastest growing economies is the Indian economy. Agriculture, especially in rural areas where $55 \%$ of people live, is the main source of livelihoods. Agriculture also makes a significant contribution to export earnings, and for many sectors, it is an important source of both raw materials and demand. India 's agriculture sector has made enormous strides over the last 50 years. The Green Revolution was the keystone of the agricultural achievement of India, transforming the nation from the stage of food shortage to self-sufficiency by using high yielding varieties and higher levels of fertiliser and pesticide inputs. However, during this era, the indiscriminate and excessive use of chemicals posed a long-term question mark on agricultural sustainability, bringing sustainable agricultural production to the center. In meeting and addressing social, ecological and economic issues, organic farming plays a crucial role. In addition to irrational use of chemical inputs over the past 
four decades, industrial agricultural practises have resulted not only in loss of natural habitat balance and soil health, but have also caused many hazards such as soil erosion, decreased groundwater level, soil salinization, fertiliser and pesticide contamination, genetic erosion, environmental impacts, decreased food quality ( Ram,2003). Farmers no longer consider agriculture a viable proposition, and a substantial number of farmers have actually committed suicides (Deshpande, 2002). Shifting from subsistence farming into commercial agriculture. In other words, practices of local indigenous farming have been phased out and replaced by techniques of industrial farming. Techniques that lead to an agricultural enterprise that is unviable and unsustainable. Alternative farming methods and crop growing strategies should be of greater significance in this context. The theory of organic farming is to attract farmers worldwide. With its different advantages over current agricultural practices. It is basically an agricultural approach that promotes and improves biological processes without the use of inorganic treatments, such as pesticides or genetically modified animals. There is viable and successful organic farming (Reganold et al., 1993; Letourneau and Goldstein, 2001; Mader et al., 2002). Numerous statesupported entities, non-governmental organisations (NGOs) and citizens have begun experimenting with methods of organic food production in the recent past. By returning all the waste to it mainly by compost to reduce the space between NPK addition and removal from the soil, a great focus is placed on preserving the soil fertility (Chhonkar, 2002). The rising population pressure today has pushed many nations to use pesticides and fertilisers to improve farm productivity to meet their needs everincreasing requirements for food. However, the prolonged and unsustainable use of chemicals has contributed, along with environmental contamination, to human and soil health hazards. Therefore, farmers in developing countries are encouraged to turn their current farms into organic farms. India 's agricultural activities date back more than 4000 years, and it has more than 4000 years of sustainable practices. In this area, there is a lot of indigenous agriculture. As told in Arthashastra, farmers in the Vedic era have a good knowledge of fertility of soil, choice of seeds, plant protection techniques, sowing seasons, and crop sustainability in many lands. (P.K. Sofia 2006). In India, there were 43.1 million hectares of organic farmland, including in conversion areas and with 2 hectares million suppliers. Organic producers in the world are in Asia (36\%), a percentage. Africa (29\%) and Europe (17\%) followed. In light of recent developments in organic farming, this chapter aims to put together numerous concerns. In relation to organic farming, it traces the history of organic farming and reviews the global and Indian scenarios. Organic farming is a holistic agricultural management approach that promotes and enhances the sustainability of the agro-ecosystem, including biodiversity, ecological cycles and soil biological activity. The organic farming method emphasises the use of organic matter to enhance soil properties, reduce health risks associated with the food chain and achieve closed nutrient cycles, which are key factors for sustainable agriculture (Cardelli et al., 2004). While organic farms yield 10-15\% less on average than conventional farms, the lower yields are balanced by lower input costs and higher margins. For the last decade, its annual growth rate has been around 20 percent (Lotter, 2003). Accounting for more than 31 million hectares of land and producing more than US\$ 26 billion in annual trade worldwide (Escobar and Hue, 2007). In more than 130 countries, organic agriculture is now being practiced. Countries with a combined area of 30.4 million hectares constitute approximately 0.65 percent of the world's total agricultural 
land (Willer et al., 2008). For the area protected by organic agriculture. The prime role is held by Australia, followed by China, Argentina, the USA, Italy and several other nations (Willer et al., 2008). India, while it ranks second in terms of the total number of certified organic farms $(44,926)$, ranks 13 th in terms of organic agriculture. In India, approximately 528,171 hectares (including approved and organically converted) are covered by organic agriculture, accounting for about 0.3 percent of the total agricultural land. While our country has witnessed an economic boom over the last few decades, there are still three significant and interrelated issues that need to be of serious concern to the agricultural sector. Although the production of cereals has increased over 4.5 times during the last 60 years (Lal, 2004). As far as animal domestication is concerned, India is one of the oldest civilizations. In response to extreme climate changes, human adaptation and migration are known from Palaeo records. Climate improvement and the fact that more energy is needed to produce the same calories of food energy for hunting and gathering than for agricultural practices ( $\mathrm{Li}$ and Rutger, 2000). In accordance with the intrinsic dynamics of human populations, the focus of animal domestication has shifted from hunting to agricultural use and the related shift in food and lifestyle habits. Since tropics provide sufficient humidity for the growth of food and feed plants, in the early half of the Holocene, South and Central Asia became the centres of earliest plant and animal domestication, leading to the start of the Holocene agriculture Activities (Gupta et al., 2006). In the area watered by the Indus River and its tributaris, domestication of animals and plants started about 10000-7000 cal years $\mathrm{BP}$ in the northwestern part of India (Allchin and Allchin, 1997). Consumers are asked for cleaner and better foods provided by local systems in a more ecological and authentic way. It is assumed that organically produced food and food goods fulfil these demands (Rembialkowska, 2007). For both consumers and producers, organically produced foods have become one of the best options. Organic foods are part of Go Green Style of Life. But the question is: what does organic farming mean? (Chopra et al., 2013). Northbourne said the farm itself should have biological completeness; it must be a living entity; it must be a unit that has a healthy organic existence within itself (Nourthbourne, 2003). 'It is focused on minimal use of off-farm inputs and management practices that preserve, sustain and boost environmental harmony (Winter and Davis, 2006). In conventional farming, insects, weeds, and pests can be eliminated by synthetic pesticides and chemicals, and growth factors such as synthetic hormones and fertilisers increase the growth rate (Worthington, 2001). In conventional farming, insects, weeds, and pests can be eliminated by synthetic pesticides and chemicals, and growth factors such as synthetic hormones and fertilisers increase the growth rate (Magnusson et al., (2003) and Brandt and MØlgaord (2001). In comparison to conventionally grown foods, organically grown foods, especially leafy vegetables and tubers, have higher dry matter AFSSA (2003). Woëse et al., (1997) and Bourn and Prescott (2002) found same results. In agriculture, organic farming has become increasingly important, given the growing number of issues posed by the use of chemical fertilisers and pesticides. The promotion of these techniques of organic farming only leaves India better positioned to reap the enormous export potential of these foods. They are less polluted with pesticide residues and pathogenic species as organically grown crops are cultivated without the use of pesticides and sewage sludge such as Listeria monocytogenes or Salmonella sp. or Escherichia coli (Van Renterghem et al., 1991; Lung et al., 2001; Warnick et al., 2001). Organic foods also ensure greater 
health advantages and benefit and protect our health. Organic farming increases soil physico-biological properties consisting of more organic matter, biomass, higher enzymes, increased soil stability, improved percolation of water, retaining capacity, lower water and wind erosion compared to traditional soil farming (Fliessbach and Mäder, 2000; Edwards, 2007; Fileßbach et al., 2007). Organic farming requires a higher level of labour, so it produces per farm, more income-generating jobs (Halberg, 2008) (Table 1-5).

\section{Status of organic farming}

\section{World status}

Now-a-days organic agriculture is increasing day by day, almost 141 countries in the world are growing organic foods in the year 2007, as predicted. In addition to agricultural land, certified organic aquaculture accounts for 0.4 $\mathrm{M}$ ha. Around 65 per cent of the countries participating in organic farming are developing countries. The regions with the highest organically grown areas are under agricultural land management: Oceania, Europe and Latin America. Australia, Argentina and Brazil have more organic areas. Approximately more land of the organically managed land in the world, nearly 11 Mha, is located in developing countries. There is more land in Latin American countries, while the second and third places are in Asia and Africa, respectively. At a global level, in 2008, the organic land area expanded by almost one year. Compared to data for the year 2006, 1.5 M ha. Approximately 28\% (or 1.4 Mha) more organically controlled land (including 0.9 M.ha of in-conversion land in Brazil for which no data was previously available) was recorded for Latin America. Organically controlled land increased by 0.33 Mha $(+4$ percent) and by 0.33 Mha (+ 4 percent) in
Europe 0.18 Mha in Africa (+27 percent) (Willer and Klicher, 2009). Chart reveals that Austria has the largest percentage of organic farming land (8.40 percent), followed by Switzerland, the UK and Germany. In India, organic farming accounts for just $0.03 \%$ of the country, although there is enormous scope for adding more land to organic.

\section{Organic area development in India}

India has immense potential for a significant breakthrough in organic agriculture, which is largely untapped. The graph shows that the organic area of India in 2005 was 0.186 million hectares and the wild selection area was 2.386 million hectares. In 2013, the number increased to 0.51 million hectares and 5.18 million hectares, respectively. In India, the total area of both organic and wild harvests raised from 2.57 million hectares in 2005 to 5.69 million hectares in 2013. The compound growth rate of the organic area and wild selection area of India was 7.45 percent and 12.87 percent from 2005 to 2013, respectively. The compound growth rate of the total organic area of India, including wild selection, was 11.52 percent and the variance coefficient during the same time was 0.53 percent. It is evident that the wild selection area 's growth rate has increased more than the real organic area in India.

Agriculture plays a critical role in a developing country like India. It also plays a role in improving the economy of the country, in addition to meeting the rising Indian population's food requirements. Between 1960 and 2000, the implementation of the Green Revolution technology increased large varieties of a inputs such as fertilizers and pesticides have added a great deal in this regard. But beyond that food insecurity and poverty continue to prevail prominently in our country. Chemical biopesticides and fertilizers have a detrimental effect on the 
environment, to improve health issues and much more gricultural crop yield per hectare, which increased food supply in developing countries by 12-13 percent. India has previously practiced organic farming, but new practices in agriculture have driven it to the walls. Vermicomposting has beneficial effects on the production and wellbeing of plants and handles organic waste in an environmentally friendly manner.

\section{Effect of organic farming on crop productivity}

A well-known method for growing crop yields is the addition of organic matter to the soil. The application of organic materials has improved the yield of rice grain and straw (A.R.Shrama et.al, 1990). While comparable with FYM, spent mushroom and rice straw compost application increased rice grain yields over NPK fertiliser by 20 percent (Ranganathan et al., 1997). The 7.5 t FYM ha 1 application produced significantly more grain and straw yields over unfertilized fields. With growing rates of FYM, all the yield attributing characters of rice increased (Singh et al., 1998). Organic dhaincha (Sesbania aculeata $L$ ) farming has made major increases in the yield of rice and chickpea grains (Singh et al., 2001). Many researchers have stated that earthworm activity is greater in an organically controlled area than in inorganic agriculture (Edwards et al., 1974).

\section{Effect of Organic farming on soil fertility}

After decomposition, the organic matter releases macro- and micronutrients into the soil solution, which is made accessible to the plants, resulting in greater absorption. By manipulating soil properties on a long-term basis, organic farming has been able to maintain higher crop yields and improve soil quality and productivity (Minhas and Sood 1994). After 4 years, organic and low-input agricultural practices contributed to a rise in organic biomass, soluble phosphorus, exchangeable potassium, and $\mathrm{pH}$. The reserve pool of stored nutrients and the stable EC degree of relativity were also preserved (Clark et al., 1998; Gaur et al., 2002). Standard composting takes a long time to lead or does not contribute to the organic pool or to a substantial loss of organic materials such as CO2 (Subha rao, 1999). The use of compost increased the soil $\mathrm{pH}$ from 6.0 without compost to 6.5 with compost and decreased the population of broadleaf weed by 29 percent and the population of grassy weed by 78 percent (Bulluck et al., 2002). Nutrient supply capacity was reduced through degradation of soil organic matter, especially on soils with a high initial organic matter content in the rice-wheat cropping system (Yadav et al., 2000). Enhanced organic matter content and labile nutrient status in organic farming (S. Subbiah and K. Kumaraswamy 2000). The decrease in soil reaction may be attributed to organic compounds in the form of green and root biomass added to the soil that created more humus and organic acids during decomposition (Laxminarayana and Patiram, 2006).

\section{Effect of organic farming on Soil Biological Properties}

Compost contains bacteria, actinomycetes, and fungi; thus, microorganisms were not only added but also stimulated by a fresh supply of humic material (Balasubramanian et al., 1972; Gaur et al., 1973). A lot of carbon was applied to the composting content, thus increasing the heterotrophic bacteria and fungi in the soil and further increasing the activity of the soil enzymes responsible for transforming inaccessible types of nutrients into available forms. Farming activities have had an impact on the biophysiochemical properties of the soil. Bacteria, protozoa, nematodes, and arthropod densities were 
higher in soils under organic farming than in soils under traditional farming (Wu et al., 2002). Organic fertility amendments increased beneficial soil microorganisms, decreased pathogen population, total carbon and cation exchange capacity, and decreased bulk densities, thereby improving soil quality (Bulluck et al., 2002).

\section{Major challenges of organic farming in India}

\section{Lack of awareness}

The most major drawback faced in the development of organic farming is the failure of the level of government policy making to make a firm decision to support organic farming. Until such a simple and concise path is available in terms of both financial and technical support, from the level of the Centre to the level of the Panchayat, nothing can lead to simple regulatory action.

The use of bio-fertilizers and bio pesticides includes the agricultural community's knowledge and determination. In order to improve productivity, information about the availability and usefulness of supplementary nutrients for soil enrichment is also important. There is also a lack of attention to compost / organic manure use. During the months where the required moisture level is missing on the ground, the organic matter is released. In the process, all the manure transforms into waste. Of course, the necessary operation is laborintensive and expensive, but the desired results need to be achieved.

\section{Output marketing problems}

It is found that their marketability must be ensured before the start of production of organic crops and that they must also be guaranteed at a premium over conventional goods. The difficulty in obtaining a premium price would be a failure, at least during the time required to achieve the degree of productivity of conventional crops.

\section{Scarcity of Bio-mass}

Many experts and well-informed farmers are not sure if the organic materials will make all the nutrients vacant with the quantities needed. Although the material is available, but cannot fulfill all requirements.

\section{Insufficent supporting Infrastructure}

Given the adoption of the NPOP in 2000, state governments have yet to devise policies and a reliable mechanism to implement them. There are only four accreditation organisations in service. Fruit, vegetables, tea, coffee and spices are limited to their expertise. The certifying organisations are ineffective

\section{High input cost}

In the context of the conventional farming method, the small and marginal farmers in India have been practicing a sort of organic farming. They use sustainable resources for local or own farms and carry out farming practices in an environmentally friendly climate. However, the cost of organic inputs is now higher than that of chemical fertilisers and pesticides provided by industry, among other inputs used in traditional farming systems.

\section{Marketing problem of organic input}

The incorrect supplies and the low level of knowledge of the growers also contribute to the problem. Higher profit margins for chemical fertilisers and retail pesticides, strong advertising campaigns by producers and distributors are other major issues that affect India's organic input markets. 
Table.1 Historical outlook of organic farming

\begin{tabular}{|l|l|}
\hline *Ancient period & HISTORICAL OUTLOOK OF ORGANIC FARMING \\
\hline Oldest period & $\begin{array}{l}10000 \text { years old, from the Neolithic period, practised by ancient } \\
\text { civilizations such as Mesopotamia, Hwang Ho basin, etc. }\end{array}$ \\
\hline Ramayana & $\begin{array}{l}\text { All dead things are converted into living things that nourish life- } \\
\text { the rotting corpse or stinking garbage returned to Earth. Such is } \\
\text { mother earth's alchemy-as interpreted by C. Rajagopalachari }\end{array}$ \\
\hline Mahabharata (5500 BC) & $\begin{array}{l}\text { Mention of the celestial cow Kamadhenu and its role in human } \\
\text { life and soil fertility }\end{array}$ \\
\hline $\begin{array}{l}\text { Kautilya Arthashastra } \\
\text { (300 BC) }\end{array}$ & Some manures have been reported, like oil cake, animal excreta. \\
\hline $\begin{array}{l}\text { Brihad-Sanhita (by } \\
\text { Varahmihir) }\end{array}$ & $\begin{array}{l}\text { Mentioned how to select manures and the manuring methods for } \\
\text { different crops. }\end{array}$ \\
\hline Rig Veda (2500-1500 BC) & $\begin{array}{l}\text { In Ria Veda 1, 161, 10,2500- 1500 BC, Green Manure is listed } \\
\text { in Atharva Veda II 8.3, (1000 BC) as organic manure. It is } \\
\text { mentioned in Sukra (IV, V, 94, 107-112) that the plant should be } \\
\text { nourished with goat dung, sheep, cow, water as well as meat to } \\
\text { cause healthy development. }\end{array}$ \\
\hline Holy Quran (590 AD) & $\begin{array}{l}\text { what you take from the soil must be returned to it, which means } \\
\text { recycling or residue after harvesting. }\end{array}$ \\
\hline
\end{tabular}

Table.2 Main milestones in current era of organic farming

\begin{tabular}{|c|l|}
\hline $\begin{array}{l}\text { Sir Albert Howard } \\
\text { (1900-1947) }\end{array}$ & $\begin{array}{l}\text { The founder of modern organic agriculture, Pusa, } \\
\text { Samastipur, India, invented the method of organic } \\
\text { composting (mycorrhizal fungi) and published the } \\
\text { document An Aqriculture Testament. }\end{array}$ \\
\hline Rudolph Steiner ( 1922) & $\begin{array}{l}\text { In Germany, a German spiritual philosopher built a } \\
\text { biodynamic farm. }\end{array}$ \\
\hline J.I. Rodel (1950), USA & $\begin{array}{l}\text { The words sustainable agriculture and method of organic } \\
\text { cultivation have been popularised }\end{array}$ \\
\hline IFOAM & $\begin{array}{l}\text { Establishment of 'International Federation of Orqanic } \\
\text { Agriculture Movement", in 1972 }\end{array}$ \\
\hline One Straw Revolution & $\begin{array}{l}\text { The book was written by an eminent microbiologist in Japan, } \\
\text { Masanobu Fukoka (1975). }\end{array}$ \\
\hline EU Regulation & EU Regulation on Organic Food, 199 \\
\hline Codex & Codex guideline on organic standard, 1999 \\
\hline
\end{tabular}


Table.3 Percentage of the region under organic farming in the overall area under cultivation of the world's various countries in 2004

\begin{tabular}{|c|c|}
\hline Country & Percentage of area under organic farming \\
\hline USA & 0.24 \\
\hline UK & 4.23 \\
\hline Germany & 4.11 \\
\hline Argentina & 1.71 \\
\hline Austria & 8.41 \\
\hline Australia & 2.21 \\
\hline Japan & 0.12 \\
\hline Switzerland & 7.95 \\
\hline South Africa & 0.06 \\
\hline Italy & 3.71 \\
\hline India & 0.05 \\
\hline Pakistan & 0.07 \\
\hline Srilanka & 0.06 \\
\hline
\end{tabular}

Table.4 Organic area development in India area in hectares

\begin{tabular}{|c|c|c|c|c|c|c|}
\hline Year & $\begin{array}{l}\text { Organic } \\
\text { Area (A) }\end{array}$ & $\begin{array}{l}\text { Annual } \\
\text { Growth } \\
\text { Rate }\end{array}$ & $\begin{array}{l}\text { Wild } \\
\text { Collection } \\
\text { (B) }\end{array}$ & $\begin{array}{l}\text { Annual } \\
\text { Growth } \\
\text { Rate }\end{array}$ & $\begin{array}{l}\text { Total Organic } \\
\text { Area }(A+B)\end{array}$ & $\begin{array}{l}\text { Annual } \\
\text { Growth } \\
\text { Rate }\end{array}$ \\
\hline 2005 & 185937 & ......... & 2385963 & & 2571900 & $\ldots \ldots$. \\
\hline 2006 & 422259 & 132.48 & 2385963 & 0.00 & 2818222 & 9.58 \\
\hline 2007 & 1030311 & 138.36 & 1769689 & -25.83 & 2800000 & 0.65 \\
\hline 2008 & 101800 & -1.19 & 2781530 & 57.18 & 3799530 & 35.70 \\
\hline 2009 & 1180000 & 15.91 & 3360000 & 20.80 & 4540000 & 19.49 \\
\hline 2010 & 780000 & -33.90 & 3650000 & 8.63 & 44300005561792 & -2.42 \\
\hline 2011 & 1084266 & 39.01 & 4477526 & 22.67 & 5200000 & 25.55 \\
\hline 2012 & 500000 & -53.89 & 4700000 & 4.97 & 5690000 & -6.50 \\
\hline 2013 & 510000 & 2.00 & 5180000 & 10.21 & 11.52 & 9.42 \\
\hline CGR & 7.45 & ........ & 12087 & 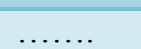 & 0.53 & \\
\hline $\mathrm{CV}$ & 0.59 & $\ldots \ldots$ & 0.55 & ........ & & \\
\hline
\end{tabular}

(Source FIBL-AML Organic data network survey 2000-2015)

Table.5 Important organic crops exported from India

\begin{tabular}{|c|c|c|}
\hline S. No. & Type of Commodity & \multicolumn{1}{|c|}{ Products } \\
\hline $\mathbf{1}$ & $\begin{array}{c}\text { Spices } \\
\text { Cardamom, black paper, Ginger, turmeric, nutmung, chilli, } \\
\text { clove and vanilla }\end{array}$ \\
\hline $\mathbf{2}$ & Plantation & Tea, coffee, cocoa \\
\hline $\mathbf{3}$ & Pulses & Red gram, black gram \\
\hline $\mathbf{4}$ & Fruits & Mango, banana, pine apple, passion fruit, orange, cashew \\
\hline $\mathbf{5}$ & Nut & Walnut \\
\hline $\mathbf{6}$ & Vegetable & Okra, brinjal, onion, tomato, patato \\
\hline $\mathbf{7}$ & Oilseeds & Seasame, castor, sunflower \\
\hline $\mathbf{8}$ & Others & Cotton, herbal extracts \\
\hline
\end{tabular}

Source (APEDA) 

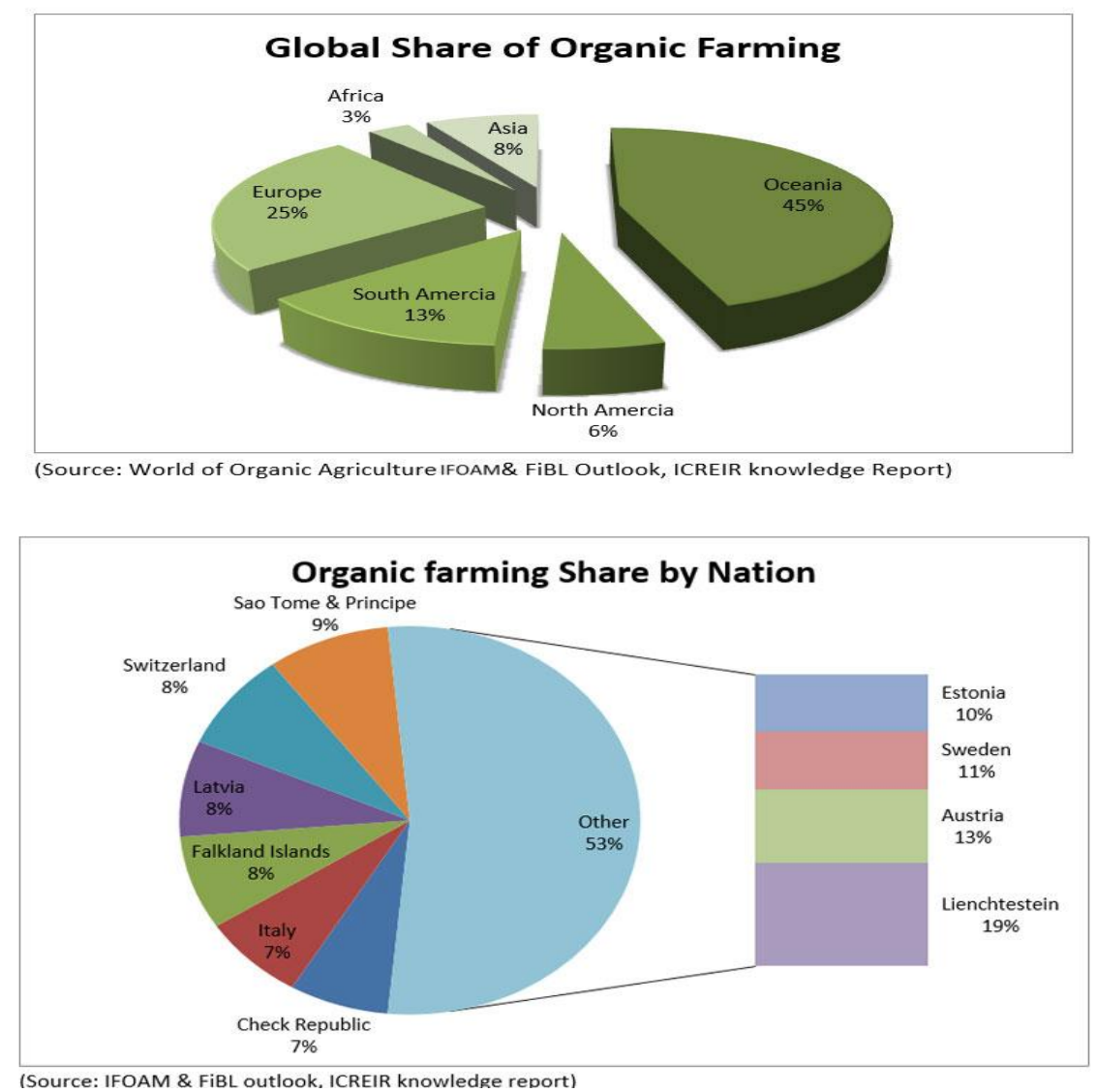

\section{Low yields}

In certain situations, farmers suffer some yield losses when discarding synthetic inputs when their farming system is converted from traditional to organic. Higher profit margins for chemical fertilisers and retail pesticides, strong advertising campaigns by producers and distributors are other major issues that affect India's organic input markets. In certain situations, farmers suffer some yield losses when discarding synthetic inputs when their farming system is converted from traditional to organic. It will take some time to restore maximum biological activity in terms of growth of beneficial insect populations, legume nitrogen fixation, pest suppression and fertility issues, and the result is a decrease in yield rates in the interregnum. It could also be likely that it would take years for organic development on the farm to be made possible.
In conclusion the agriculture is the mainstay of economic policies in many developing countries, including India, and is the ultimate engine of national economic development and poverty alleviation. It has vast opportunities for rural jobs and the stability of livelihoods. The alternative to organic agriculture is gaining momentum. Many countries have been able to transform a large percentage of their cultivated areas into organic agriculture. Indian agriculture has developed primarily by using natural inputs to increase crop yield as an ecologically sustainable technique. Suitable crops / products should be classified on a regional basis for organic production which has demands from the international market. Because of its responsibilities to ensure food and nutritional stability, the entire region can not afford to go for organic at a time. India has great potential for organic 
farming with complex agro-climatic conditions and many products are manufactured organically in India. The limitations of organic farming in India are high prices for organic products and a lack of adequate marketing functions in domestic markets.

\section{References}

AFSSA. (2003). Report on Evaluation of the nutritional and sanitary quality of organic foods (Evaluation nutritionnelle et sanitaire des aliments issus de l'agriculture biologique, in French), AFSSA, 164. http://www.afssa.fr. Accessed 3 August 2018

Allchin, B., and Allchin, F. R. (1997). Origins of a Civilization: the Prehistory and Early Archaeology of India.

APEDA- Personal Communication.

Balasubramanian, A., Siddaramappa, R., and Rangaswami, G. (1972). Effect of organic manuring on the activities of the enzymes hydrolysing sucrose and urea and on soil aggregation. Plant and Soil, 37(2), 319-328.

Bjørn, G., and Fruekilde, A. M. (2003). Cepa onions (Allium cepa L) grown conventionally and organicallysimilarities and differences. Grøn Viden, 153, 1-6

Bourn, D., and Prescott, J. (2002). A comparison of the nutritional value, sensory qualities, and food safety of organically and conventionally produced foods. Critical reviews in food science and nutrition, 42(1), 1-34

Brandt, D. A., Brand, T. S., and Cruywagen, C. W. (2000). The use of crude protein content to predict concentrations of lysine and methionine in grain harvested from selected cultivars of wheat, barley and triticale grown in the Western Cape region of South
Africa. South African Journal of Animal Science, 30(1), 22-25. Bulluck Iii, L. R., Brosius, M., Evanylo, G. K., and Ristaino, J. B. (2002). Organic and synthetic fertility amendments influence soil microbial, physical and chemical properties on organic and conventional farms. Applied Soil Ecology, 19(2), 147-160.

Cardelli, R., Levi-Minzi, R., Saviozzi, A., and Riffaldi, R. (2005). Organically and conventionally managed soils: biochemical characteristics. Journal of Sustainable Agriculture, 25(2), 63-74

Chhonkar, P. K. (2002). Organic farming myth and reality. Fertilizer News, 1-9..

Chopra, A., Rao, N. C., Gupta, N., and Vashisth, S. (2013). Come sunshine or rain; organic foods always on tract: A futurist perspective. International Journal of Nutrition, Pharmacology, Neurological Diseases, 3(3).

Clark, M. S., Horwath, W. R., Shennan, C., and Scow, K. M. (1998). Changes in soil chemical properties resulting from organic and low-input farming practices. Agronomy Journal, 90(5), 662-671

Dangour, A. D., Allen, E., Lock, K., and Uauy, R. (2010). Nutritional composition and health benefits of organic foods-using systematic reviews to question the available evidence. The Indian journal of medical research, 131(4), 478-480..

Deshpande, R. S. (2002). Suicide by farmers in Karnataka: agrarian distress and possible alleviatory steps. Economic and Political Weekly, 2601-2610.

Edwards, C. A., and Lofty, J. R. (1974). Ttte invertebrate fauna of the Park Grass Plots. I. Soil fauna. Roth. Fjcp. Stat. Rep. 1974. Part, 2, 133-154

Edwards, S., and Arefayne, A. (2007, May). The impact of compost use on crop yields in Tigray, Ethiopia. In 
International conference on organic agriculture and food security, FAO, Rome (Vol. 2).

Escobar, M. O., Hue, N. V., and Pandalai, S. (2007). Current developments in organic farming. Recent Research Development in Soil Science, 2, 29-62.

Fließbach, A., Oberholzer, H. R., Gunst, L., and Mäder, P. (2007). Soil organic matter and biological soil quality indicators after 21 years of organic and conventional farming. Agriculture, Ecosystems and Environment, 118(1-4), 273-284

Gaur, A. C. (1975). All Indian coordinated project on microbiological decomposition and recycling of farm and city wastes. Project Report, Indian Council of Agricultural Research, Poona, India.

Gaur, A. C., Sadasivam, K. V., Vimal, O. P., Mathur, R. S., and Kavimandan, S. K. (1973). Studies on the humification of organic matter in a red Rakar soil. Zentralblatt für Bakteriologie, Parasitenkunde, Infektionskrankheiten und Hygiene. Zweite Naturwissenschaftliche Abteilung: Allgemeine, Landwirtschaftliche und Technische Mikrobiologie, 128(1-2), 149-161.

Gupta, A. K., Anderson, D. M., Pandey, D. N., and Singhvi, A. K. (2006). Adaptation and human migration, and evidence of agriculture coincident with changes in the Indian summer monsoon during the Holocene. CURRENT SCIENCE-BANGALORE-, 90(8), 1082.

Halberg, N. (2008). Energy use and green house gas emission in organic agriculture. Organic agriculture and climate change. The contribution that organic agriculture and our dietary choices can make to the mitigatin of global warming
Lal, R. (2004). Soil carbon sequestration in India. Climatic Change, 65(3), 277296.

Laxminarayana, K. (2006). Effect of integrated use of inorganic, biological and organic manures on rice productivity and soil fertility in ultisols of Mizoram. Journal of the Indian Society of Soil science, 54(2), 213-220.

Letourneau, D. K., and Goldstein, B. (2001). Pest damage and arthropod community structure in organic vs. conventional tomato production in California. Journal of Applied ecology, 38(3), 557-570.

Li, Z., and Rutger, J. N. (2000). Geographic distribution and multilocus organization of isozyme variation of rice (Oryza sativa L.). Theoretical and Applied Genetics, 101(3), 379-387.

Lotter, D. W. (2003). Organic agriculture. Journal of sustainable agriculture, 21(4), 59-128.

Lung, A. J., Lin, C. M., Kim, J. M., Marshall, M. R., Nordstedt, R., Thompson, N. P., and Wei, C. I. (2001). Destruction of Escherichia coli O157: H7 and Salmonella enteritidis in cow manure composting. Journal of food protection, 64(9), 1309-1314.

Mäder, P., Fliessbach, A., Dubois, D., Gunst, L., Fried, P., and Niggli, U. (2002). Soil fertility and biodiversity in organic farming. Science, 296(5573), 1694-1697

Magnusson, M. K., Arvola, A., Hursti, U. K. K., Åberg, L., and Sjödén, P. O. (2003). Choice of organic foods is related to perceived consequences for human health and to environmentally friendly behaviour. Appetite, 40(2), 109-117.

Minhas, R. S., and Sood, A. (1994). Effect of inorganics and organics on the yield and nutrient uptake by three crops in a 
rotation on an acid alfisol. Journal of the Indian Society of Soil Science, 42(2), 257-260.

Nourthbourne, C.J., 5th Lord. (2003). Look to the Land, 2nd Rev Spec edn. Sophia Perennis, Hillsdale, NY; First Ed. 1940. J.M. Dent and Sons.

Organic Foods Production Act of 1990, Pub. L. No. 101-624, §§ 2101- 2123, 104 Stat. 3935 (codified at 7 U.S.C.6501$6522)$.

Ram, B. (2003). Impact of human activities on land use changes in arid Rajasthan: Retrospect and prospects. Human Impact on Desert Environments, Eds: P. Narain, S. Kathaju, A. Kar, MP Singh and Praveen Kumar, Scientific Publishers, Jodhpur, 44-59.

Ranganathan, D. S., and Selvaseelan, D. A. (1997). Mushroom spent rice straw compost and composted coir pith as organic manures for rice. Journal of the Indian Society of Soil Science, 45(3), 510-514.

Reganold, J. P., Palmer, A. S., Lockhart, J. C., and Macgregor, A. N. (1993). Soil quality and financial performance of biodynamic and conventional farms in New Zealand. Science, 260(5106), 344-349.

Rembialkowska, E. (2000). Wholesomeness and sensory quality of the potatoes and selected vegetables from the organic farms. Fundacja Rozwoj SGGW, Warszawa.

Renterghem, B. V., Huysman, F., Rygole, R., and Verstraete, W. (1991). Detection and prevalence of Listeria monocytogenes in the agricultural ecosystem. Journal of applied bacteriology, 71(3), 211-217.

Shanmei, W., Ingham Elaine, R., and Dunxiao, H. (2002). Soil microfloral and faunal populations in an organic agroecosystem in Oregon, USA. In 17. World congress of soil science,
Bangkok (Thailand), 14-21 Aug 2002.

Sharma, A. R., and Mittra, B. N. (1990). Complementary effect of organic, bioand mineral fertilisers in rice based cropping system. Fertiliser News, 35(2), 43-51.

Singh, G., Singh, O. P., Yadava, R. A., Singh, P. P., and Nayak, R. (1998). Response of rice (Oryza sativa) varieties to nitrogen levels in flash flood conditions. Indian Journal of Agronomy, 43(3), 506-510

Singh, K. M., Sharma, I. P., and Srivastava, V. C. (2001). Effect of FYM, Fertilizer and Plant Density on Productivity of Rice-Wheat Sequence. JOURNAL OF RESEARCH-BIRSA AGRICULTURAL UNIVERSITY, 13(2), 159-162

Singh, K. N., Prasad, B., and Sinha, S. K. (2001). Effect of integrated nutrient management on a Typic Haplaquant on yield and nutrient availability in a rice-wheat cropping system. Australian Journal of Agricultural Research, 52(8), 855-858.

Sofia, P. K., Prasad, R., and Vijay, V. K. (2006). Organic farming-tradition reinvented.

Subba, Rao.N.S., "Organic matter decomposition," in Soil Microbiology, pp. 255-270, Oxford and IBH Publishing, New Delhi, India, 1999.

Subbiah, S., and Kumaraswamy, K. (2000). Effect of different manure-fertiliser schedules on the yield and quality of rice and on soil fertility. Fertiliser News, 45(10), 61-67.

Warnick, L. D., Crofton, L. M., Pelzer, K. D., and Hawkins, M. J. (2001). Risk factors for clinical salmonellosis in Virginia, USA cattle herds. Preventive veterinary medicine, 49(3-4), 259-275.

Willer, H. and Klicher, L. (Eds) (2009) The World of Organic Agriculture: Statistics and Emerging Trends. IfOM, 
Bonn, FiBL, Frick, ITC, Geneva

Willer, H., Yussefi, M., and Sorensen, N. (Eds.). (2010). The world of organic agriculture: statistics and emerging trends 2008. Earthscan.

Winter, C.K., Davis, S.F. (2006). Organic food. Journal of Food Science, 71: $117-124$.

Woese, K., Lange, D., Boess, C., and Bögl, K. W. (1997). A comparison of organically and conventionally grown foods - results of a review of the relevant literature. Journal of the Science of Food and Agriculture, 74(3), 281-293.

Yadav, R. L., Dwivedi, B. S., and Pandey, P. S. (2000). Rice-wheat cropping system: assessment of sustainability under green manuring and chemical fertilizer inputs. Field Crops Research, 65(1), 15-30.

\section{How to cite this article:}

Lanje Shivaji Namdevrao. 2020. Organic Farming: Status, Challenges and towards Sustainable Agriculture. Int.J.Curr.Microbiol.App.Sci. 9(12): 93-105.

doi: https://doi.org/10.20546/ijcmas.2020.912.013 